\title{
Does Technology-Enabled Service Quality affect Organizational Competencies?
}

\author{
Mehvish Rasheed (Corresponding Author) \\ MS Scholar, Department of Management Sciences, \\ The Islamia University of Bahawalpur, Pakistan \\ E-mail: mehvishrasheed28@yahoo.com \\ Dr. Abdul Latif \\ Professor, Department of Management Sciences, \\ The Islamia University of Bahawalpur, Pakistan \\ E-mail: drabdullatif@hotmail.com
}

Received: July 13, 2011 Accepted: August 11, $2011 \quad$ DOI: 10.5296/jpag.v1i2.791

\begin{abstract}
Purpose: This paper attempts to explain the effect of information technology on service quality and measures the impact of technology enabled service quality through customer satisfaction towards banks' performance.

Design/methodology/approach: Enormous literature and various previous experimental studies regarding service quality have been assessed. Furthermore, a model based on the literature is proposed, which elaborates the effect of technology on service quality and illustrates the customer satisfaction towards banks' performance in the context of technology enabled service quality. Hypotheses were developed and tested in the light of the earlier studies and literature.

Findings: On the basis of analysis and findings, it can be concluded that service quality and banks' financial performance are associated through customer satisfaction in the environment of automated service quality in banking.
\end{abstract}

Keywords: Organizational Competencies; Information Technology; Service Quality; Performance; Banks 


\section{Introduction}

The recent technological revolution has changed the perceived service quality of customers and values to access lots of services. The Information Technology (IT) is being used extensively in almost every field of life including banking sector. Different organizations are making major investments in IT for attaining the future benefits and competitive advantage. During the past two decades, there has been an astonishing distribution of computers and IT, which highlights the issue of effect of IT on the organizational performance as well.

Customer satisfaction is a significant driver for enhanced organizational performance, particularly in the banking sector for better competition. Banking is gaining importance because it is not only an essential facility, but it also promotes business operations. Strategic growth, survival and performance of a bank may be enhanced by customer satisfaction and service quality in today's worldwide and boundary-less market. To deliver superior banking services to the customers, IT is widely used in the existing competitive surroundings.

The human-human relationship of retail banking has changed in service delivery and considered unnecessary due to rise of IT and internet services. In this way, modern or technology based banking has replaced the traditional banking. This study determines that the performance of banks and the service quality influence the satisfaction level of customers, and that the technology enabled service quality has a significant and positive effect on banks' performance and customer satisfaction.

\section{Literature Review}

\subsection{Information Technology}

IT "is a common term that describes any technology that helps to create, influence, process, accumulate, correspond, and/or distribute information" (William Sawyar, 2005 cited in Shaukat and Zafarullah, 2009). Other researchers e.g. Shelly et al., (2004) stated that IT comprises hardware, software, databases, networks and other connected components, which are used to construct information systems. The demand for IT steps forward along with socio-economic expansion in developing countries. In a short time, IT has become the backbone of contemporary industrial civilization and the major driver for the growth of both developing and developed countries (Vasudevan, 2003; Long and Long 1999 cited in Shaukat and Zafarullah, 2009).

Much of the concentration IT has acquired is due to its exclusive power, speed, variety of functions performed in the workplace, its current and persistent presence. Although various definitions are possible, but IT can be defined as vehicle that creates widespread use of microelectronics and automatic commands or software. IT systems are often elastic, reprogrammable, and repeated or self-acting. They can record, process, communicate, and respond to huge amounts of information penetrated by users, established from the environment, or accumulated internally (Handel.M.J, 2003).

\subsection{Organizational Competencies}

"A focus on organizational competencies is more serious to attaining team alignment, 
effective execution and the right allotment of inadequate resources than to focus on strategic goals” (Coates, 2008).An organizational competency is an expression that has been used in the world of performance management for many years. It is normally used by human resource experts and organizational change advisors to refer the universe of employee skills that the company ought to have in line to achieve their goals and plans. The concept of organizational competencies is the most misinterpreted and misapplied in the corporate world. Organizational competencies are frequently thought to be the employee skills rather than the convincing cross company core competencies that compel integrated business implementation and management configuration (Coates, 2008).

A broader explanation of organizational competencies focuses on the initial word i.e. "organizational". Under this explanation, the organization becomes the focal point because it is the organization as a whole that ought to perform - not just an individual worker, therefore the definition of organizational competencies itself ought to change. Under this approach, the organization must pace outside itself and estimate abstractly that what things, as an organization, it does on a continuing, systemic origin that allows it to accomplish its task. In general, but not for all times, the organization must have one such competency in excess but not lots of them. In this framework, organizational competencies can be described as a blend of necessary skills, essential information, suitable performance measures and the right corporate culture that the company requires to achieve its mission (Coates, 2008).

\subsection{Effects of Information Technology in Organization}

To enhance the service quality and to gain competitive advantage, organizations must use technology to gather information on market demands and exchange it (Sangeetha \& Mahalingam, 2011). Several researchers have examined the positive consequences of IT on quantitative performance variables of the corporations, which are incomes and profits (Parthasamthy and Sethi, 1993; Kelly, 1994; Earls.al, 1996; O’ Dell and Elliot, 1999 cited in Shaukat and Zafarullah 2009). Whereas, Frankin (1997), Olalla (2000), Schmid et al., (2001), Zee and Han (2002) cited in Shaukat and Zafrullah (2009) have examined the increase and/or decrease in different qualitative performance indicators i.e. customer satisfaction, company image, job interest of employees, stake holders confidence, interoffice link etc. and also have found positive impact.

According to Wheelen and Hunger (2000), the organization performance is an accumulated result of organizational process and activity, measured by organization's working and activity. The organizational management manages the organizational performance, control and customer value, as it influences reputation of organization. Commonly organizational work measures include organization effectiveness, productivity/ efficiency and industry ranking (Wetherbe et al., 1999 cited in Shaukat and Zafarullah, 2009). Efficiency is defined as "minimum utilization of resources and getting maximum output" and effectiveness is "how well job gets done” (Robbin and Coulter, 2003 cited in Shaukat and Zafarullah 2009).

\subsection{Effect of Information Technology in Banking Sector}

In financial sector, IT is broadly used and heavily invested. First time by the use of "check 
handling, bookkeeping credit analysis and ATMs”, financial sector has incorporated electronic data handling in their procedures (Bender, 1986; Martini, 1999; Vasudevan, 2003 cited in Shaukat and Zafarullah, 2009).

Currently, there has been a tremendous growth in the service industries by the use of IT, and the banking sector is the most prominent example to use IT-linked products in "internet banking, electronic payments, security investments, and information exchanges” (Berger, 2003). Now- a- days, with a smaller amount of manpower, banks offer various services to its clients in efficient and effective way. By observing its developing progress, it appears that IT can bring equal contribution to financial benefits (Ho and Mallick, 2006).

In banking sector, the usage of computer first started in early 1950s, and the first user of computer in banking sector was Bank of America. For the commercial banks, the best achievement of online and real time computerization was the usage of ATM (developed in 1973 by Don Wetzel). New York took the lead to introduce ATMs at commercial banks for the first time (Shelly and Cashman, 2004 cited in Shaukat and Zafarullah, 2009).

Due to the availability of ATMs over wide geographical areas, the bank accounts are easily accessed from any location the customer wants, and ultimately its benefits are enhanced. The more availability of ATM locations increases the value of its network, and the final network size of the banks is determined by the customer as the value of a bank's network (Ho and Mallick, 2006).

\subsection{Service Quality}

Nowadays, with an ever increasing competition, service quality has become a popular area of academic investigation, and has been recognized as a key factor in keeping competitive advantage and sustaining satisfying relationships with customers (Zeithmal et al., 2000; Wang and Wang, 2007). Service quality has been defined in services marketing literature as an overall evaluation of service by the customers. Perceived service quality is believed to be resulting from comparison between customers' previous expectations about the service and their perceptions after actual service experience (Asubonteng et al., 1996; Parasuraman et al., 1985 cited in Ganguli and Roy, 2011).

Grönroos (1982) described the total service quality as customer's perception of difference between the expected and the perceived service quality. He also defined the concept of perceived service quality as the outcome of an evaluation process, where the consumer compares his expectations with the service he perceives or has received (Wang and Wang, 2007).

Service quality is considered as a critical success factor for modern service businesses. It has been discussed conceptually as a potential alternative to traditional skills and resources, as well as empirically tested as a potential driver of improving business performance (Rapert and Wren, 1998; Newman, 2001; Kang and James, 2004 cited in Akroush, 2009).

Service quality is commonly noted as a critical prerequisite and determinant of competitiveness for establishing and sustaining satisfying relationships with customers. 
Previous studies suggest that service quality is an important indicator of customer satisfaction (Spreng and Machoy, 1996 cited in Wang and Wang, 2007). Focus and adherence to service quality help organizations for their successful operations and gaining competitive advantage over others (Morre, 1987 cited in Wang and Wang, 2007).

Many empirical studies found that there is a positive and significant relationship between service quality and business performance (e.g., Rust et al, 1995; Zeithaml et al, 1996; Kang and James, 2004; Chumpitaz and Paparoidamis, 2004; Lai et al, 2005; Akroush, 2008a, 2008b cited in Akroush, 2009). Previous studies also concluded that service quality exerts a significant positive influence on service business performance assessed based on financial and non-financial measures (Zeithaml et al., 1996; Zeithaml, 2000; Duncan and Elliot, 2002; Akroush, 2008a, 2008b cited in Akroush, 2009).

\subsection{Technology-Enabled Service Quality}

Due to increase in IT based services, customers expect higher service quality all the time (Kolter and Keller, 2006 cited in Wang and Wang, 2007). Bresnahan (1997) enlightens that employers must adopt IT based production processes so as to improve service quality or increase efficiencies and thereby to increase profits. In each of these cases, organizational change is required for effective use of IT (Bresnahan et.al, 1999). Most of the studies link technology enabled service delivery with online or internet based service quality (Collier and Bienstock, 2006; Parasuraman et al., 2005; Santos, 2003; Van Riel et al., 2001; Wolfinbarger and Gilly, 2003 cited in Ganguli and Roy, 2011).

Dabhlkar (1994) stated that to make customer participation more widely possible, technology-based services have established new service delivery options in organizations. For example, touch screen "kiosks" are used by customers to order take away food, and the banks have extensively distributed automatic teller machines to withdraw, transfer money, make deposits into accounts or accomplish any other dealings e.g. balance related queries (Ombati et al., 2010).

\subsection{Technology-Enabled Service Quality in Banks}

The 'bank' is generally understood as "an institution that holds a banking license granted by financial supervision authorities. Under the authorities, the bank conducts the most fundamental banking services like accepting deposits and loans, and other financial services” (Wang and Wang, 2007). The banking industry is one of the earliest adopters of service automation as providers recognized that technological innovations in banking services represented an opportunity to differentiate themselves from competitors in what was otherwise a mature market (Devlin, 1995 cited in Proenca and Rodrigeus, 2011).

Customers have altered the ways in which they access many services because of the growth of technology-based self-service designs in recent years, including banking services (Bobbitt and Dabholkar, 2001 cited in Proenca and Rodrigeus, 2011). In banking services, most of the studies have scrutinized the service quality linked to the specific technologies like internet banking, ATM banking and phone banking (Al-Hawari et al., 2005; Curran and Meuter, 2005 cited in Ganguli and Roy, 2011). 
The rapid advancement in IT has had a profound impact on the banking industry and from the last two decades it has become a tool for the wider financial sector that facilitates "banks' organizational structures, business strategies, customer services” and other linked functions. In financial services industry, the recent IT revolution has exerted extensive effects on economies (Jayamaha, 2008). Banks have willingly implemented self-service technologies (SSTs) of different types e.g. ATM, telephone banking, internet banking, and mobile banking” - all of them can be used by consumers independently, without any need for interaction with bank employees (Meuter et.al, 2000 cited in Proenca and Rodrigeus, 2011).

In 1950s, when the first mechanical book keeping machine was installed in banks, the technological revolution was started. Over the next few decades, automation became widespread in banking and bankers recognized that they could make their "labor-intensive information-handling processes” automated by the use of computers. In 1968, the first ATM was introduced as a cash dispenser in USA. It requires no face-to-face interaction between the customer and bank staff while "withdrawing funds, accounts inquiries and transferring funds" and the introduction of ATMs has also facilitated to improve customer ease and decrease in costs (Jayamaha, 2008).

The banking environment throughout the world considerably changed through "regulatory, structural and technological factors" during the past two decades (Angur et al., 1999 cited in Sangeetha and Mahalingam, 2011). To force the awareness of banking institutions, service quality has become an important measure of organizational performance and it remnants the forefront of services marketing prose and practice (Lasser et al., 2002 cited in Sangeetha and Mahalingam, 2011). Without adding physical branches, banks are now able to offer more diversified and suitable financial services by the expansion of IT. "The present day ATMs are more sophisticated machines that can scan the customer and a bank teller, accept cash or cheques, facilitate customer application for loans and allow for face-to-face discussion with a service representative via video" (Jayamaha, 2008).

Brady and Cronin (2001) highlighted in their study that "service quality can also be treated as a second order construct consisting of interaction, physical environment and outcome quality” (Ganguli and Roy, 2011). The internet services have expanded widely, causing low-cost and suitable financial network and helping customers to attain the banking services whenever and wherever they require. Core banking architecture needs a change due to internet and web-based services. The introduction of new core banking systems by some banks and their links with the improved telecommunication networks has enabled banking transactions to be done on-line, and in real time in contrast to the batch-processing mode used earlier. The combination of e- trading with the internet banking and website of the bank is a notable feature as well. These IT advancements have enabled banks to gradually replace manual work by automated procedures with on-line and real time processing (Jayamaha, 2008).

Consumer confidence has been unfavorably exaggerated because of the global economic slowdown and turbulence in the financial markets across the world. In this business scenario, the banking industry has become highly competitive. IT is extensively used in this 
competitive environment to deliver banking services to the consumers. In fact, rise of IT and the internet in particular, have changed the consumption process of retail banking as human-human interactions in service delivery is becoming increasingly redundant (Bitner et al., 2000 cited in Ganguli and Roy, 2011). So, traditional banking or branch banking is increasingly being replaced by the technology-based banking (Ganguli and Roy, 2011).

Human-human interactions or face-to-face interactions between customers and bank employees are being substituted by interaction of customers with technology. In fact, a large number of IT tools are being utilized to increase the efficiency and effectiveness of service delivery (Marshall, 2006 cited in Ganguli and Roy, 2011). With the pattern of consumer behavior changing with the increasing use of technology in the delivery of banking services, there is a need to cultivate customers' confidence in using the technology-based services. This is so because customers may not be ready to avail the technology-based service delivery and there is proof of growing customer frustration while interacting with the technology based service delivery interfaces (Parasuraman, 2000 cited in Ganguli and Roy, 2011).

\subsection{Customer Satisfaction towards Banks' Competency}

Customer satisfaction is an important driver for better organizational performance especially in the banking sector due to increased competition and innovation. Several studies measured the relationship between customer satisfaction and performance of the firm (e.g. Anderson et al., 1994; Al-Hawari and Ward, 2006 cited in Ahmed, 2011). In today's global and borderless market, product/service quality and customer satisfaction may increase the performance of banks for successful survival. It is found that there is direct and positive relationship between perceived quality and level of satisfaction (Iglesias and Guille'n, 2004 cited in Ahmed, 2011).

Studies have examined the relationship of customer satisfaction and customer loyalty with service quality (Andreassen and Lindestad, 1998; Cronin and Taylor, 1992; Dabholkar et al., 2000; Zeithaml et al., 1996 cited in Ganguli and Roy, 2011). Even in the banking sector research has examined the impact of service quality on customer satisfaction and loyalty (Krepapa et al., 2003; Levesque and McDougall, 1996; McDougall and Levesque, 2000; Ndubisi and Wah, 2005 cited in Ganguli and Roy, 2011). With the emergence of technology-based banking, many researchers have also looked at the perceptions of customers regarding the service quality of technology banking (Al-Hawari et al., 2005; Curran and Meuter, 2005 cited in Ganguli and Roy, 2011).

In case of electronic banking, Al-Hawari et al. (2005) identified five dimensions of service quality, which are ATM quality, telephone-banking quality, internet banking quality, customer perception of core service and customer perception of price. For online banking, Yang et al. (2004) found the following dimensions of service quality: reliability, responsiveness and competence, ease of use, security and product portfolio. Besides these, other dimensions identified for technology banking are accuracy, feedback/complaint management, queue management, accessibility, (Ombati et al., 2010) personalization / customization and customer service (Joseph et al., 1999; Joseph and Stone, 2003 cited in Ganguli and Roy, 2011). 
The installation of customer friendly technology e.g. ATMs, telephone and internet banking services, as a means of delivering traditional banking services has become commonplace in recent years as a way of maintaining customer loyalty and increasing market share. Traditional brick and mortar banks are using technology to meet the competitive challenge posed by online banks, as well as a method of reducing the cost of providing services that were once delivered exclusively by bank personnel (Joseph et al., 2003 cited in Ombati et al., 2010).

Managers in virtually all industries understand that providing quality customer service is a key strategic component in firm profitability. The importance of service delivery and its impact on improving satisfaction and retention of customers, improving sales \& market share, and improving corporate image cannot be overstated (Lewis et al., 1994). As with most other service providers, banks have moved quickly to invest in technology as a way of controlling costs, attracting new customers, and meeting the convenience and technical innovation expectations of their existing and potential customers (Pyun et al., 2002 cited in Ombati et al., 2010).

It is found that there is a significant relationship between service quality and financial performance (Duncan and Elliot, 2002 cited in Ahmed, 2011). Customer satisfaction plays an inter-mediator role in the relationship between service quality and financial performance of the banks in Australia (Al-Hawari and Ward, 2006 cited in Ahmed, 2011). Service quality is considered a critical success factor for modern service businesses. Service quality has been discussed conceptually as a potential alternative to traditional skills and resources, as well as empirically tested as a potential driver of improving business performance (Rapert and Wren, 1998; Newman, 2001; Kang and James, 2004). Research has invested much effort on the conceptualization and measurement of service quality and its relationship with business performance (e.g., Cronin, 2003; Chumpitaz and Paparoidamis, 2004 cited in Akroush, 2009).The interest is largely driven by the realization that high service quality results in customer satisfaction, loyalty, greater willingness to recommend to someone else, reduction in complaints and improved customer retention rates (Levesque and McDougall, 1996 cited in Sangeetha and Mahalingam, 2011).

\section{Research Objective(s)}

The main objective of this study is to theoretically investigate the affect of technology-enabled service quality on organizational competency in banking sector.

The sub objectives of the study include:

- To identify the effect of information technology on service quality

- To measure the impact of technology enabled service quality through customer satisfaction towards banks' performance 


\section{Macrothink \\ Journal of Public Administration and Governance \\ ISSN 2161-7104 \\ 2011, Vol. 1, No. 2}

\section{Proposed Model for Service Quality}

A model has been proposed as depicted in Figure 1. The model describes the effect of information technology on service quality. The combination of information technology and service quality delivers technology enabled service quality as articulated by the model. The model further elaborates that technology enabled service quality enhances banks' performance through the satisfaction of banks' customers.

Figure 1: Proposed Model for Research
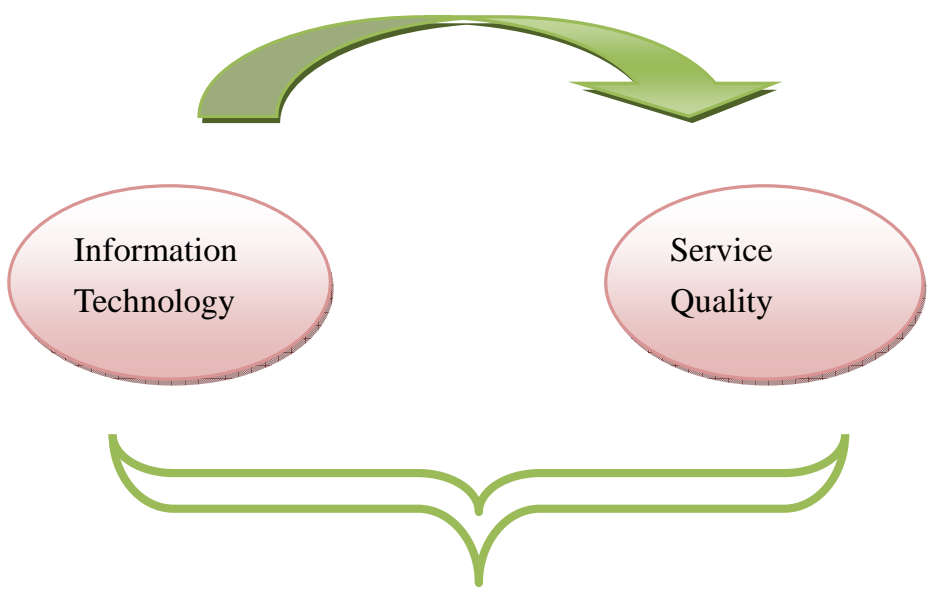

Technology-En

abled Service

Quality

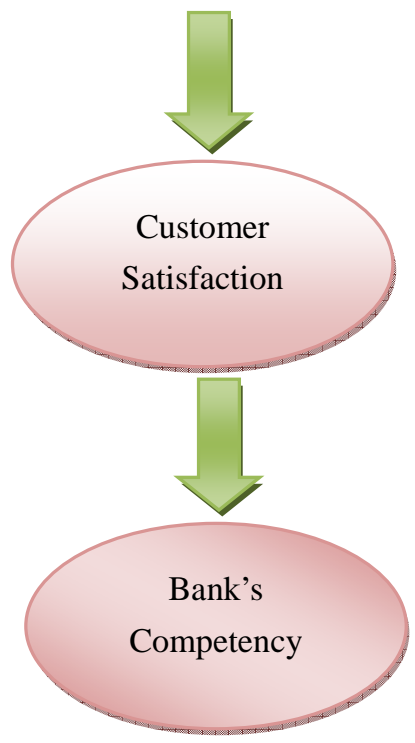




\section{Hypotheses}

H1: There is an effect of technology on service quality

H2: There is a relationship between technology enabled service quality and banks' performance through customer satisfaction

\subsection{Technology Effect}

Lewis and Mitchell (1994) elaborate service quality as a perceived point at which a service meets customer's wants and expectations. Parasuraman (1985) clarified service quality as the differentiation among the customers' expected and perceived service. Perceived quality will be less than satisfactory level when the expectations are more than performance and customers will not be satisfied (Ombati et al., 2010). Bobbitt and Dabholkar (2001) make clear that customers have changed the fashion in which they access many services because of the development in technology based self-service formats in recent times (Proenca and Rodrigeus, 2011).

Kolter and Keller (2006) state that customers are gradually expecting advanced services in this technologically advanced era due to the expansion in IT related applications, and in the meanwhile majority of them are expecting to save more time and wishing for more ease (Wang and Wang, 2007). According to Davis et al. (1989) technology enabled service quality is the prerequisite of information and services via a bank to its customers by the use of computer, telephone, internet etc (Ombati et al., 2010).

Bresnahan (1997) point out that managers prefer IT-based production process to develop service quality and / or to increase efficiencies and profits, but whatever is the goal, efficient use of IT brings positive changes in organizations (Bresnanah et.al., 1999). Many researchers like Collier and Bienstock, 2006; Parasuraman et al., 2005; Santos, 2003; Van Riel et al., 2001; Wolfinbarger and Gilly, 2003 conducted studies related to technology based service delivery including online or internet based services (Ganguli and Roy, 2011).

Dabholkar (1994) explained, how technology based services have prepared new service provision alternatives obtainable by organizations for creating customer involvement more widely possible (Ombati et al., 2010). According to Devlin (1995), organizations when trying to discriminate themselves from competitors, which was otherwise a maturate market, the banking industry was one of the initial adopters of service automation as contributors recognized the technological innovations that banking services represented (Proenca and Rodrigeus, 2011). IT developments have made possible for the banks to progressively change manual work by automated actions with on-line authentic point dealing (Jayamaha, 2008).

Marshall (2006) enlightens that now a day, customers have direct interaction with technology instead of human-human connections or face-to-face connections that was between customers and banks employees. In order to improve the competence and efficacy of delivering a service, numerous IT tools are utilized on a wide scale (Ganguli and Roy, 2011). Many banks have introduced new banking systems and developed their associations with the enhanced 
telecommunication system, which has allowed banking transactions to be made on-line, in comparison to the methods that used batch processing previously. The incorporation of electronic buying and selling through internet banking and website of the bank is also a distinguished aspect. Developments of IT have facilitated the banks to progressively replace physical work by automated dealings by means of on-line real time processing (Jayamaha, 2008).

To provide banking services to the customers, IT is being used widely in these competitive surroundings. Bitner (2000) argued that augmented IT and predominantly the internet have altered the utilization method of retail banking as human-human communications in delivering a service is becoming progressively superfluous. Therefore, the technology-based banking service is rapidly replacing the traditional banking or branch banking (Ganguli and Roy, 2011). The advancement in IT has facilitated banks to expand their network, offering new and suitable financial services, even without accumulation of physical branches. The modern ATMs are more stylish machines that can examine the consumer, make possible customer request for loans and permit face-to-face conversation (Jayamaha, 2008).

Al-Hawari (2005) and Curran and Meuter (2005) taking into consideration the previous studies, explained that perceptions of customers concerning the service quality of banking is effected by the emergence of technology based banking (Ganguli and Roy, 2011). Prendergast and Marr (1994) elaborated that time consuming projects, repetitive, human fault and extensive access to banking related services are reduced by the effect of technological development. In addition, they argue that technology helps the customer to get information in a real time, which is otherwise, time consuming and sometimes difficult to obtain in face-to-face interactions. Many studies e.g. Boyer (2002), Janda (2002) and Zeithaml (2002) explained that involvement among service quality and business performance has constrained attention towards e-service, online service and internet transactions (Ombati et al., 2010).

Joseph (1999) and Joseph \& Stone (2003) discovered the dimensions of technology banking are "accuracy, feedback/complaint management, queue management, accessibility, personalization/ customization and customer service”. While talking about electronic banking Al-Hawari (2005) recognized five components of service quality: “ATM quality, telephone banking quality, Internet banking quality, customer perception of core service and customer perception of price”. In addition, Yang (2004) established the following elements of service quality: "reliability, responsiveness, competence, ease of use, security and product portfolio" (Ganguli and Roy, 2011). Therefore, based on literature discussed, we accept the first hypothesis and conclude that IT affects service quality.

\subsection{Technology Enabled Service Quality and Banks' Performance through Customer Satisfaction:}

Duncan and Elliot (2002) found that service quality is directly related to the financial performance of banks (Ahmed, 2011). Studies were carried out in traditional face-to-face context to examine the impact of service quality on financial performance of banks in the programmed service context and evaluated the mediating role of customer satisfaction (Al-Hawari and Ward, 2006). 
Many researchers investigated the impact of service quality on customer satisfaction and loyalty in banking sector (Ganguli and Roy, 2011). Mugambi (2006) proved that studies have been prepared on part of service distinction and customer satisfaction in the banking industry (Ombati, et al, 2010).

Literature also suggest that customer satisfaction has the intervening function between service quality and the performance of a bank. Razak (2007) found that service quality has positive relationship with customer satisfaction. Ennew (1996) argued that service quality has direct impact on profitability of a bank. Ahmed (2011) examined the customers' judgment towards satisfaction and its effect on the banks' performance and service quality.

Anderson (1994) and Al-Hawari \& Warid (2006) described that due to enhanced competition, customer satisfaction is considered a crucial element for superior organizational performance particularly in banking sector. Relationship between the performance of the firm and customer satisfaction has been measured in several studies. Newman and Cowling (1996) stated the importance of service quality for banks due to the association among quality, productivity and profitability. Similarly, service quality also effects customer satisfaction and their intentions to switch (Ahmed, 2011). Many researchers investigated, whether customer satisfaction and customer loyalty are effected by generic service quality dimensions, and concluded that "ease of technology used and reliability" and customer service has an increased and significant effect on customer satisfaction (Ganguli and Roy, 2011).

Iglesias and Guille'n (2004) explained that banks' performance is augmented by service quality and customer satisfaction for booming survival in today's international and borderless market. Ahmed (2011) stated that perceived quality is directly and positively related to satisfaction level. Levesque and McDougall (1996) articulated that the concentration is basically determined through awareness demonstrating that high service quality achieves the customer satisfaction, loyalty, greater eagerness to suggest to others, decrease in objections and enhanced customer retention rate (Sangeetha and Mahalingam, 2011).

Another study argues that the level of customer satisfaction with the bank is extensively and positively associated with the quality of automated service offered by a particular bank (Al-Hawari and Ward, 2006). In banking industry, there is a direct connection between technology and service quality and that the service offerings to the customers are enhanced by making use of technology (Ombati et al., 2010).

In context of automated banking service, various studies add to the current body of knowledge that customer satisfaction has a significant role in understanding financial performance. Wiele (2002) stated, in consistent with the literature, that financial performance and customer satisfaction are in direct relationship with each other (Al-Hawari and Ward, 2006). The results of this study demonstrated that financial performance is affected by automated bank service quality with mediating role of customer satisfaction. So, the customer satisfaction is considered as the key construct in banks' financial performance. Most importantly, to enhance financial performance, the stipulation of elevated principles of automated service quality is supposed to be under control for further enhancing customer satisfaction (Al-Hawari and Ward, 2006). Prior literature demonstrates that there is a positive 
and significant relationship between technology-enabled service quality and banks' performance through customer satisfaction, which entirely support our second hypothesis.

\section{Conclusion}

The purpose of this study is to expand the understanding of how IT affects the service quality by examining the relationship of technology-enabled service quality and banks' performance through customer satisfaction. Previous literature was taken into consideration to analyze the effect of IT on service quality and found the strong and positive relationship between the technology-enabled service quality and the banks' performance through customer satisfaction. IT has changed the entire world and helped the world to turn it into a global village. Organizational performance is also improved by the use of IT. Since last two decades, the usage of IT is growing at an astonishing rate and companies are enormously spending on it in order to take advantage of its full potential and as a source of competitive advantage. It is analyzed that service organizations are investing huge amount on IT and, in the same way, it is aggressively applied efficiently used in the banking sector.

In the scenario of current study, with the help of previous literature, the authors proposed a model of service quality, which explains the effect of technology enabled service quality on banks' performance. Moreover, the findings indicate that the technology enabled service quality has a positive and significant effect on banks performance in the context of customer satisfaction. It is also confirmed by various studies that the financial measure of banks' performance, influenced by the technical quality is majorly affecting the banks’ profitability.

So, this study will help to better understand the connection among service quality, banks' performance and customer satisfaction. Aligned with given results, in conclusion, we can say that IT investments have significant and positive effects on the organizations' performance.

\section{References}

Akroush, M. (2008a) 'Exploring the mediation effect of service quality implementation on the relationship between service quality and performance in the banking industry in Jordan', Global Business and Economics Review (GBER): An International Journal, Vol. 10, No. 1, pp.98-122.

Akroush, M. (2008b) 'The effect of service quality on banks marketing performance: an empirical investigation of managers' perspectives', Journal of Dirasat, Administrative Sciences, January, Vol. 35, No. 1, pp.199-218.

Al-Hawari, M., Hartley, N. and Ward, T. (2005), "Measuring banks' automated service quality: a confirmatory factor analysis approach”, Marketing Bulletin, Vol. 16, May, pp. 1-19.

Al-Hawari M, Ward T (2006),. The effect of automated service quality on Australian banks' financial performance and the mediating role of customer satisfaction, Mark. Intel. Plan.. 24(2): 127-147.

Anderson EW, Fornell C, Lehman DR (1994),. Economic consequences providing quality and customer satisfaction, Working paper (Report 93-112), Marketing Science Institute, 
Cambridge, M.A.

Andreassen, T.W. and Lindestad, B. (1998), "Customer loyalty and complex services: the impact of corporate image on quality, customer satisfaction and loyalty for customers with varying degrees of service expertise”, International Journal of Service Industry Management, Vol. 9 No. 1, pp. 7-23.

Asubonteng, P., McCleary, K.J. and Swan, J.E. (1996), "SERVQUAL revisited: a critical review of service quality”, The Journal of Services Marketing, Vol. 10 No. 6, pp. 62-81.

Ahmed, P.K. (1998), 'Culture and climate for innovation', European Journal of Innovation Management, vol. 1, no. 1, pp. 30-43.

Ahmed, A., Kashif-ur-Rehman and Safwan, N. (2011) 'Testing a model of Islamic banking based on service quality, customer satisfaction and bank performance', African Journal of Business Management, vol. 5, no. 5, pp. 1880-1885.

Akroush, M.N. (2009) 'Does service quality implementation mediate the relationship between technical service quality and performance: an empirical examination of banks in Jordan', Int. J. Services, Economics and Management, vol. 1, no. 3, pp. 209-232.

Al-Hawari, M. and Ward, T. (2006), 'The effect of automated service quality on Australian banks financial performance and the mediating role of customer satisfaction', Marketing Intelligence \& Planning, vol. 24, no. 2, pp. 127-147.

Bender, D. (1986), 'Financial impacts of information processing', Journal of Management Information System, 3, 2: 232-238.

Berger, A. N. (2003), The economic effects of technological progress: evidence from the banking industry, Journal of Money, Credit, Banking, 35 (2), 141-176.

Bitner, M.J., Brown, S.W. and Meuter, M.L. (2000), “Technology infusion in service encounters”, Journal of the Academy of Marketing Science, Vol. 28 No. 1, pp. 138-49.

Bobbitt, L. and Dabholkar, P. (2001), "Integrating attitudinal theories to understand and predict use to technology-based self-service, The internet as an illustration”, International Journal of Service Industry Management, Vol. 12 No. 5, pp. 423-50.

Boyer et al., (2002), E-services: operations strategy - a case study and a method for analyzing operational benefits, Journal of Operations Management, Vol. 20 No. 2, pp. 175-88.

Bresnahan, T. (1997) “Computerization and Wage Dispersion: An Analytic Reinterpretation.” Mimeo. Stanford University.

Brady, M.K. and Cronin, J.J. (2001), "Some new thoughts on conceptualizing perceived service quality: a hierarchical approach”, Journal of Marketing, Vol. 65 No. 3, pp. 34-49.

Bresnahan, T.F., Brynjolfsson, E. and Hitt, L.M. (1999) 'Information Technology and Recent Changes in Work Organization Increase the Demand for Skilled Labor', IT, Organization and Labor Demand, p.1-45. Online available at: 
http://www.stanford.edu/ tbres/research/Brookings\%20volume.pdf

Chumpitaz, R. and Paparoidamis, N. (2004) 'Service quality and marketing performance in business-to-business markets: exploring the mediating role of client satisfaction', Managing Service Quality, Vol. 14, Nos. 2/3, pp.235-248.

Chung Wang and Zheng Wang,( 2007), 'The impact of internet on service quality in the banking sector'. Online available at: http://epubl.ltu.se/1653-0187/2006/07/LTU-PB-EX-0607-SE.pdf

Cullen Coates \& Associates, (2008), 'Organizational Competencies', Online available at: http://www.cullencoates.com/images/Managing_Organizational_Competencies_.pdf

Collier, J.E., and Bienstock, C.C., (2006), "Measuring service quality in e-retailing”, Journal of Service Research, Vol. 8, No. 3, pp. 260-75.

Cronin, J.J. Jr and Taylor, S.A. (1992), "Measuring service quality: a reexamination and extension”, Journal of Marketing, Vol. 56 No. 3, pp. 55-68.

Cronin, J.(2003), 'Looking back to see forward in services marketing; some ideas to consider', Managing Service Quality, Vol. 13, No. 5, pp.332-337.

Curran, J.M. and Meuter, M.L. (2005), “Self-service technology adoption: comparing three technologies”, Journal of Services Marketing, Vol. 19 No. 2, pp. 103-13.

Dabholkar, P. (1994), Technology based service delivery, Advances in Services Management, Vol. 3 pp.241-71.

Dabholkar, P., Shepherd, C.D. and Thorpe, D.I. (2000), “A comprehensive framework for service quality: an investigation of critical conceptual and measurement issues through a longitudinal study”, Journal of Retailing, Vol. 76 No. 2, pp. 139-73.

Davis, F. et al. (1989), User acceptance of computer technology, Management Science, Vol. 35 No.8, pp.982-1003.

Devlin, J. (1995), “Technology and innovation in retail banking distribution”, International Journal of Bank Marketing, Vol. 13, No. 4, pp. 19-25.

Duncan, E. and Elliot, G. (2002) 'Customer service quality and financial performance among Australian retail financial institutions’, Journal of Financial Service Marketing, Vol. 7, No. 1, pp.25-41.

Ennew, C.T. (1996). 'Good and bad Customers: the benefits of participating in the banking relationship’. International Journal of Bank Marketing, 14(2): 5-13.

Franklin, C.F. Jr. (1997), 'Emerging Technology: Enter the Extranet’, CIO Magazine, May 15, Available online: www.cio.com/archive/051597_et_content.html

Grönroos, C. (1982), Strategic Management and Marketing in the service Sector, Marketing Science, Cambridge, MA. 
Ganguli, S. and Roy, S.K. (2011), 'Generic technology-based service quality dimensions in banking', International Journal of Bank Marketing, vol. 29, no. 2, pp. 168-189.

Handel, M.J. (2003) 'Complex Picture of International Technology and Employment Emerges', SRI International, July, pp. 1-11.

Ho, S.J. and Mallick, S.K. (2006) 'The Impact of Information Technology on the Banking Industry: Theory and Empirics', pp. 1-19.

Iglesias PM, Yagu“e Guille'n MJ (2004), 'Perceived quality and price: their impact on the satisfaction of restaurant customers’, Int. J. Contemp. Hosp. Manag., 16: 373-379.

Joseph, M., McClure, C. and Joseph, B. (1999), "Service quality in the banking sector: the impact of technology on service delivery”, International Journal of Bank Marketing, Vol. 17 No. 4, pp. 182-91.

Joseph, M., and Stone, G., (2003), “An empirical evaluation of US bank customer perceptions of the impact of technology on service delivery in the banking sector”, International Journal of Retail \& Distribution Management, Vol. 31 No. 4, pp. 190-202.

Joseph et al. (2003), 'Service quality in the banking sector: the impact of technology on service delivery’, International Journal of Bank Marketing, Vol. 17 No. 4, pp. 182-91.

Kang, G. and James, J. (2004) 'Service quality dimensions: an examination of Gronroos's service quality model’, Managing Service Quality, Vol. 14, No. 4, pp.266-277.

Kelley, M. R. (1994), 'Productivity and Information Technology: The elusive connection', Management Sciences. 40, 11: 1406-1425.

Kolter, P. and Keller K.L. (2006), Marketing Management, Upper Saddle River, NJ: Prentice Hall.

Krepapa, A., Berthon, P., Webb, D. and Pitt, L. (2003), 'Mind the gap: an analysis of service provider versus customer perceptions of market orientation and the impact on satisfaction', European Journal of Marketing, Vol. 37 Nos 1/2, pp. 197-218.

Lai, K., Cheng, T., and Sdwin, C., (2005),'Effects of quality management and marketing on organisational performance', Journal of Business Research, Vol. 57, pp.446-456.

Lasser, W.M., Manolis, C., and Winsor, R.D., (2002), "Service quality perspectives and satisfaction in private banking”, Journal of Services Marketing, Vol. 14, No. 3, pp. 244-71.

Levesque, T., and McDougall, G.H.G. (1996), "Determinants of customer satisfaction in retail banking”, International Journal of Bank Marketing, Vol. 14, No. 7, pp. 12-20.

Lewis, B and Mitchell, V. (1994), 'Service quality: students' assessment of banks and societies, International Journal of Bank Marketing, Vol. 12, No.4, pp.3-12.

Long L., and N. Long. (1999). 'Computers’, Prentice Hall Inc. U.S.A: 71.

Martini M. (1999), 'Impact of IT on the Banking and financial industry', Review of economic 
conditions, 2:203-223.

Marshall, L., (2006), "Flying high on service automation”, Customer Relationship Management, February, pp. 42-3.

Meuter, M., Ostrom, A., Roundtree, R. and Bitner, M. (2000), "Self-service technologies: understanding customer satisfaction with technology-based service encounters”, Journal of Marketing, Vol. 64, July, pp. 50-64.

Morre, C.D., (1987),'The Internet and banks' strategic distribution channel decisions', International Journal of Bank Marketing, Vo; .17 No.6.

Mugambi D. (2006), A survey of Internal Service Delivery Systems in Kenya Commercial Bank, Unpublished MBA Research Project, University of Nairobi.

Ndubisi, N.O., and Wah, C.K., (2005), 'Factorial and discriminant analyses of the underpinnings of relationship marketing and customer satisfaction', International Journal of Bank Marketing, Vol. 23, No. 7, pp. 542-57.

Newman, K. (2001) 'Interrogating SERVQUAL: a critical assessment of service quality management in a high street bank', International Journal of Bank Marketing, Vol. 19, No. 3, pp.126-139.

Newman K, Cowling A., (1996). Service quality in retail banking: the experience of two British clearing banks, Int. J. Bank Mark. 14(6): 3-11.

O’Dell and S.C., Elliot, (1999), 'Sharing knowledge and best practices: the how and whys of tapping your organization's hidden reservoirs of knowledge', Health-care Forum Journal, 42: 34-37.

Olalla, M. F. (2000). 'IT in business process reengineering', International Advances in Economic research, 6, 3: 581-590.

Ombati, T.O., Magutu, P.O., Nyamwange, S.O., and Nyaoga, R.B.,., (2010), 'Technology and service quality in the banking industry', African Journal of Business \& Management (AJBUMA), vol. 1, pp. 1-16.

Parthasarthy, R., and S.P. Sethi, (1993). 'Relating strategy and structure to flexible automation: A test of fit and performance implications', Strategic management Journal, 14, 7: 529-549.

Parasuraman, A., Zeithaml, V.A., and Berry, L.L., (1985), “A conceptual model of service quality and its implications for future research”, Journal of Marketing, Vol. 49, No.4, pp. 41-50.

Parasuraman, A. (2000), “Technology readiness index (TRI): a multiple-item scale to measure readiness to embrace new technologies”, Journal of Service Research, Vol. 2 No. 4, pp. 307-20.

Parasuraman, A., Zeithaml, V.A. and Malhotra, A. (2005), "E-S-QUAL: a multiple-item scale 
for assessing electronic service quality”, Journal of Service Research, Vol. 7 No. 3, pp. 213-33.

Proenca, J.F., and Rodrigues, M.A., (2011), 'A comparison of users and non-users of banking self-service technology in Portugal', Managing Service Quality, vol. 21, no. 2, pp. 192-210.

Rapert, M., and Wren, B., (1998), 'Service quality as a competitive opportunity', The Journal of Services Marketing, Vol. 12, No. 3, pp.223-235.

Robbins S. P. and M. Coulter. (2003). 'Management', $7^{\text {th }}$ Edition, Prentice Hall, Int. U.S.A:79.

Rust, R., Zahorik, A. and Keiningham, T. (1995) 'Return on quality (ROQ): making service quality financially accountable’, Journal of Marketing, April, Vol. 59, pp.58-70.

Ranee Jayamaha, 2008. 'Impact of IT in the banking sector'. Online available at: http://www.bis.org/review/r080201d.pdf

Santos, J. (2003), "E-service quality: a model of virtual service quality dimensions", Managing Service Quality, Vol. 13 No. 3, pp. 233-46.

Schmidt, J.B, M.M. Montoya-Weiss, and A.P.Massey. (2001). 'New product development decision-making effectiveness: Comparing individuals, face-to-face teams, and Virtual teams’, Decision Sciences, 32, 4: 575.

Shelly G.B, M.E. Cashman. (2004). 'Discovering Computers: A gateway to information Web Enhanced', Thomson Course Technology Boston, U.K. 39: 74-78.

Spreng, R.A. \& Machoy, R.D. (1996) 'An Empirical Examination of a Model of Perceived Service Quality and Satisfaction’, Journal of Retailing, Summer 96.Vol 72, Issue 2, p. 201.

Sangeetha, J. and Mahalingam, S. (2011) 'Service quality models in banking: a review', International Journal of Islamic and Middel East Finance and Management, vol. 4, no. 1, pp. 83-103.

Shaukat, M. and Zafarullah, M. (2009) 'Impact of Information Technology on Organizational Performance: An analysis of Quantitative Performance Indicators of Pakistan's Banking and Manufacturing Companies', European Journal of Economics, Finance and Administrative Sciences, no. 16, pp. 39-49.

Vasudevan A. (2003). 'Some perspectives on IT up gradation in the financial sectors', Journal of Indian Institute of Bankers, 74, 1, Jan-2003:36-38.

Van Riel, A.C.R., Liljander, V. and Jurriens, P. (2001), "Exploring consumer evaluations of e-services: a portal site”, International Journal of Service Industry Management, Vol. 12No. 4, pp. 359-77.

Wetherbe J, E. Turban, and E. Mclean,. (1999), 'Information Technology for management: Making connections for strategic advantages', $2^{\text {nd }}$ edition, New York, NY, John Wiley and Sons Inc. 
Wheelen T.L and J.D. Hunger. (2000). 'Strategic Management', $7^{\text {th }}$ edition, Prentice Hall, U.S.A:231-235.

Wiele, T., Boselie, P., and Hesselink, M., (2002), "Empirical evidence for the relationship between customer satisfaction and business performance”, Managing Service Quality, Vol. 12 No. 3, pp. 184-93.

William, B.K, and S.C. Sawyar. (2005). 'Using Information Technology', 6 ${ }^{\text {th }}$ edition, McGraHill Publishing Co. U.S.A: 3, 4,147

Wolfinbarger, M.F. and Gilly, M.C. (2003), “e-TailQ: dimensionalizing, measuring and predicting e-tail quality”, Journal of Retailing, Vol. 79 No. 3, pp. 183-98.

Yang, Z., Joon, M. and Peterson, R.T. (2004), “Measuring customer perceived online service quality: scale development and managerial implications”, International Journal of Operations \& Production Management, Vol. 24 No. 11, pp. 1149-74.

Zeithaml, V.A., Berry, L.L., and Parasuraman, A. (1996), “The behavioral consequences of service quality”, Journal of Marketing, Vol. 60 No. 2, pp. 31-46.

Zeithaml, V.A., Parasuraman, A., and Malhotra. A., (2000), 'Service quality delivery through web sites: a critical review of extant knowledge', Journal of the Academy of Marketing Science, Vol.30 No.4, pp. 362-75.

Zeithaml, V. (2000) 'Service quality, profitability, and the economic worth of customers: what we know and what we need to learn', Journal of Academy of Marketing Science, Vol. 28, No. 1, pp.67-85.

Zee, W. and Han, V. D., (2002), 'Measuring the value of Information Technology', IRM press, U.S.A, 7: 47-48.

Zeithaml, V. (2002), Service-excellence in electronic channels, Managing Service Quality, Vol. 12 No. 3, pp. 135-8. 